\title{
INNOVATIVE FRAME WOOD CONSTRUCTIONS CONCEPT FOR HIGH ENERGY EFFICIENCY ECOBUILDINGS
}

Edmunds VISOCKIS, Department of Architecture and Building, Faculty of Environmental and Civil Engineering, Latvia University of Life Sciences and Technologies, Liela iela 2, Jelgava, LV-3001, Latvia, ems@ inbox.lv (corresponding author)

Oskars VITOLINS, Department of Architecture and Building, Faculty of Environmental and Civil Engineering, Latvia University of Life Sciences and Technologies, Liela iela 2, Jelgava, LV-3001, Latvia, oskars vitolins@ inbox.lv

Sandra GUSTA, Department of Architecture and Building, Faculty of Environmental and Civil Engineering, Latvia University of Life Sciences and Technologies, Liela iela 2, Jelgava, LV-3001, Latvia, sandra.gusta@1lu.lv

Raimunds SELEGOVSKIS, Institute of Energetics, Faculty of Engineering, Latvia University of Life Sciences and Technologies, Liela iela 2, Jelgava, LV-3001, Latvia, raimunds.selegovskis@1lu.lv

The aims of the research are to investigate the durability and compliance of patented innovative low or zero heat energy cons umption buildings constructions by Latvian construction standards. To develop and study high-quality, energy-efficient and long-lasting low-cost eco-buildings construction technology by using locally sourced building materials and involving local labour, using various low-cost recyclable ecological materials and their recycling residues as eco-thermal insulation. Because of the research, it was established that by using building materials of appropriate size cross-section - spruce boards and interconnecting them with screws, it is possible to make a sufficiently strong building construction frame where are in accordance with Latvian construction standards by using a significantly smaller amount of building materials. By filling the frame of the innovative construction building with thermal insulation in the appropriate thickness, it is possible to build up houses with high energy efficiency that correspond to the parameters of low or zero heat energy consumption buildings. In climatic zones, where for buildings have increased energy efficiency and thicker layer of thermal insulation requirements, it is expected that double windows and doors design solutions will be used to reduce heat loss of cold bridges, and the air gap between them increase the energy efficiency of buildings.

Keywords: wooden building constructions, energy efficiency, eco-technologies.

\section{INTRODUCTION}

The issue of the use ecological, renewable, reusable and easily recyclable resources in the environment is becoming increasingly important in the world. This is necessary to reduce the use of non-renewable resources and minerals. To reduce harmful emissions by transporting raw materials from the extraction site to production facilities where they are recycled into building materials, structural components, various systems and their control units what containing rare and in small amounts founds minerals, more widely available and rare earth metals, what require huge amounts of rock to be processed, in the production of aluminium and other non-naturally occurring metals, materials and substances. And transport the final products to distribution networks and construction sites. After the demolition of old buildings, by recycling or utilizing their components, as a result, energy consumption and the amount of harmful emissions increase even more.

The scientific work describes an innovative, highly efficient wooden frame buildings construction solutions, which differs from the existing types in that the wooden construction frame is designed to be fill up with various bulk thermal insulation materials. The width of the frame structures is determined by the necessary thickness of the thermal insulation layer required for the corresponding climatic zone in each component of the building structure - the floor, walls and roof. The aim of the research is to develop low-cost but high-energy-efficient buildings constructions solutions by using locally sourced ecological and reusable building materials and local labour.

In the scientific work, an innovative solutions of buildings constructions have been studied by used Latvia's local renewable resources - wood, which makes it possible to employ local labour to produce this type of building constructions materials. Increasing of the wood grown amounts for long terms building materials producing necessaries it will stabilize the Earth's climate, reduce the destructive consequences of its changes on a local and global scale.

In opposite of existing solutions, the innovative buildings frame constructions make it possible to use a relatively large amount of long boards without sawing the shorter ones, so that in the future by dismantling old objects, they can be much more reusable for wooden constructions or other purposes. Also, for those that require long-term

Copyright (C) 2021 The Authors. Published by Vytautas Magnus University. This is an open-access article distributed under the terms of the Creative Commons Attribution License (CC BY 4.0), which permits unrestricted use, distribution, and reproduction in any medium, provided the original author and source are credited. 
dried and high-quality preserved timber, such as high-quality musical instruments to product wooden hull components and elsewhere.

The innovative buildings frame constructions and constructions concepts make it possible to use timber more efficiently - reducing their thickness but increasing the width of the structures. The solution of using relatively thinner boards by connecting in line one after the other, ensures the higher load resistance in the plane by significantly lower consumption of construction wood materials. The resistance of lateral loads is provided by perpendicularly connected plywood boards, what ensure the fixed geometric stability of building structures.

This way of innovative approach makes it possible to significantly reduce the consumption of necessary buildings constructions materials, other associated recourses and price of final product. As well as the amount of emissions generated during their production and transportation. Less wood will be sawn down, which can continue to grow and absorbing $\mathrm{CO}_{2}$, producing $\mathrm{O}_{2}$, ensure via self-circulation of $\mathrm{H}_{2} \mathrm{O}$ by stabilizing the local and global Earth's climate and continuing to provide a living environment for flora and fauna.

The innovative building construction solution is easily applicable to the constructions of high energy efficiency buildings by creating thick external enclosing structures, which must be able take in to a larger amount of eco-thermal insulation, which stores $\mathrm{CO}_{2}$ for a long time. The cold bridges of triple glassed windows and doors are eliminated by using them twice - the outer layer must be placed closer to the outer surface of the building, the inner - closer to the indoor surfaces, but the air chamber in between provides a long-lasting, energy-efficient buffer zone.

\section{MATERIALS AND METHODS}

For the low or zero heat energy consumption eco-building experimental object frame constructions were used wood sawn timber with dimensions of $30 \times 100 \times 4800 \mathrm{~mm}$. To connect wooden planks structures, were used screws of different lengths with a diameter $6 \mathrm{~mm}$. To create bases and floor surfaces was used plywood boards with a thickness $25 \mathrm{~mm}$ and $10 \mathrm{~mm}$. Plywood boards with a thickness $10 \mathrm{~mm}$ was used to the create walls and roof planes. To create the building structures of the experimental object was used standard hand tools. The external dimensions of the 1.5storey experimental object building outside area are $8 \times 9 \mathrm{~m}$, height up to the ridge $7 \mathrm{~m}$. The interior dimensions are 6 $\mathrm{x} 7 \mathrm{~m}$, the height at the highest point of the inside edge collision of gable roof structures is $5.2 \mathrm{~m}$. The height of the first floor is $2.4 \mathrm{~m}$. The room is divided by a $250 \mathrm{~mm}$ thick mezzanine floor, and create a 1.5-storey object. The thickness of the basic thermal insulation filled in wools is $0.8 \mathrm{~m}$, in the roof is $1.2 \mathrm{~m}$. Such dimensions have been applied in accordance to the optimal dimensions of the buildings - to ensure high energy efficiency buildings parameters, geometry and the ratio of the maximal useful indoor volume in relation to the minimal surface area of external enclosing structures.

In the experimental object, as a bulk eco-thermal insulation for wall insulation, it is planned to use sawdustlime mixture with a thermal conductivity of about $0.12 \mathrm{~W} / \mathrm{m} \cdot \mathrm{k}$ (Home..., 2021), but in roof constructions hemp clumplime mixture with thermal conductivity $0.061 \mathrm{~W} / \mathrm{m} \cdot \mathrm{k}$ (Hemp..., 2021). It is planned to fill the mezzanine floor with a sound damping tree leaf-lime mixture. The total volume of thermal eco-insulation to be used is estimated at about 100 $\mathrm{m}^{3}$. This innovative construction makes it possible to store a significant amount of $\mathrm{CO}_{2}$ for a long time, which is accumulated in renewable, math times reusable and easily recyclable plant-based building construction materials. It is planned to determine the eco-insulation thermal conductivity and acoustic insulation properties. In the calculating loads of building structures, the volume weight of thermal eco-insulation materials is considered.

On outside of the external walls it is planned to install a ventilated facade with a $100 \mathrm{~mm}$ wide air gap. Inside, there is a planned $100 \mathrm{~mm}$ wide niche in the walls and sloping ceilings, which is planned to be filled up with $70 \mathrm{~mm}$ thick hard stone wool slabs covered by aluminium foil to provide additional fire safety requirements and create an infrared heat radiation screen, what will increase the building's energy efficiency and indoor air heating up speed dynamics. Above aluminium foil layer is planned to put communication wires, cables and pipelines and everything cover with indoor wooden board finish, which, except visual aesthetic effect, also ensures the absorption and emission amortisation of indoor heat, moisture and gases of the air.

The total thickness of the external walls is about $1.06 \mathrm{~m}$, but the thickness of the roof structures, including the tin roof, is about $1.50 \mathrm{~m}$. The planned energy efficiency indicators of the premises must achieve the parameters of low or zero heat energy consumption parameters, which ensure a comfortable internal microclimate as necessary for the winter conditions of eastern Latvia, without the use of basic heating. In extremely wet or cold weather, can be use minimal space heating by simple low-cost electrical appliances that do not produce harmful emissions. But in the hot summer period it is expected that it will be possible to ensure an optimal microclimate without the use of air conditioners.

The idea of innovative building construction was developed in 2017.Latvia University of Life Sciences and Technologies to the Latvia Republic Patent Office was prepared and submitted a patent application with title: "Wall and Roof building structure". Application date 21.02.2019, number P-19-10. Based on the theoretical solutions described in the patent application (Visockis et al., 2019), and received patent with the title: "Wall and roof cross frame building construction", number of patent: LV 15476 B (Visockis, 2021) was developed the building frame and the model of the innovative building structures, see Figures 1 and 2.

By use funding of the LLU program "Carrying out fundamental research LLU", scientific projectsG5"Research and development of innovative low or zero heat energy building construction technologies" and G9 "Development of innovative technologies and their research of concentration and efficient use solar thermal energy in passive and active 
systems for build-up energy efficient buildings" was partly purchased the necessary construction materials to build up the experimental object.

The development of the experimental object construction technology was performed according to the following method: by basis of the scale-reduced model dimensions, the frame structure in real dimensions by using the purchased boards was constructed horizontally lying down eco-building frame on the floor level platform. Have been measured real dimensions and developed sequence of the frame construction. Has been started build up an experimental object equivalent to a real low or zero heat energy eco-building. It is necessary to obtain reliable and in real-conditions verifiable data, to be able to develop and practically test the construction technology of such objects to make sure, that the theoretically developed solutions also work in the practical construction and operation of this type of innovative construction buildings. Figure 4 shows the beginning a practically usable experimental object pilot project construction and develop and approbate the building production technology in full size of building dimensions.

During the practical creating of the experimental object pilot project, it was found that the initially theoretic ally developed building structures need to be significantly strengthened by creating a double board structure. In this way, by slightly more than doubling the width of the building frame, where it is planned to place plywood boards perpendicularly, between the frame boards placed in one plane. Apart of the formation wall planes, they will also ensure the geometric stability required for the experimental object perpendicularly to the frame. The boards what forming the frame structure of the building in almost one plane are interconnected with the screws screwed into the perpendicular plywood board, thus way create a double frame of the building structure and sufficiently reinforcing the building structures and ensure their stability under static and dynamic loads. The building structure of the previously developed building frame was supplemented with strength elements, see. Fig. 4., and 5. Were performed calculations to determine the load-bearing strength of the building frame structures. In experimental objects build up process, the plywood boards side edges were perforated by $4 \mathrm{~mm}$ diameter holes, to be possible remove moisture of thermal insulation to the outside and ensure the requirements of SD 1: 6 in accordance of the Latvian construction standards LBN 002-19 (Regulations on the Latvian construction standard LBN 002-19, 2021). The outer plane of the roof structures was made of reused boards, which previously used for old tin roof basis, that way demonstrate the usefulness of reusable building materials.

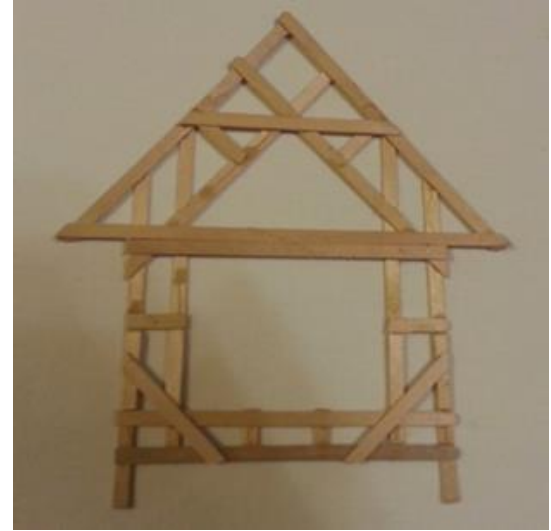

Figure 1. Prototype frame of innovative building constructions

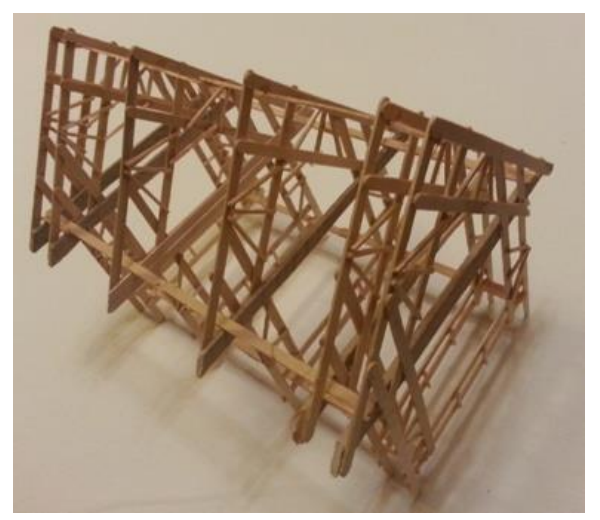

Figure 2. Model of innovative building construction

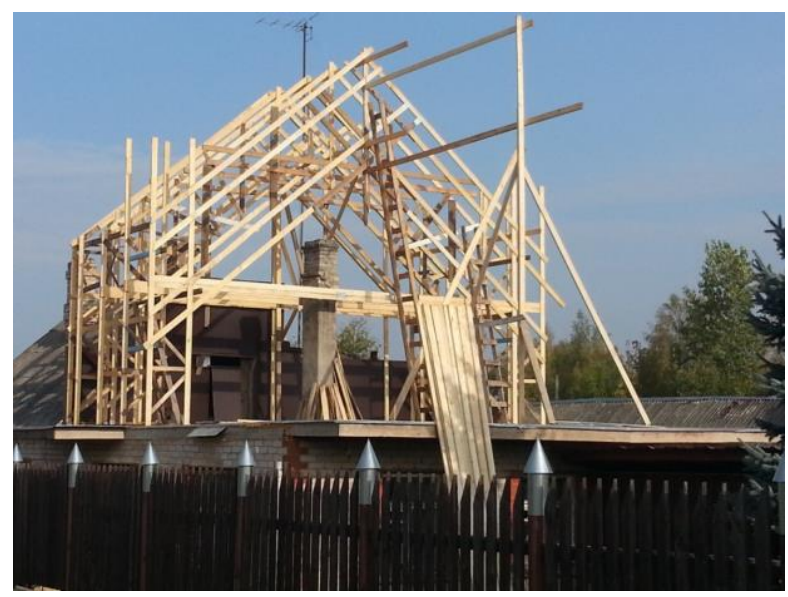

Figure 3. Construction of the experimental object roof structures level transition what give it an attractive appearance and creating double strength in to roof middle area 


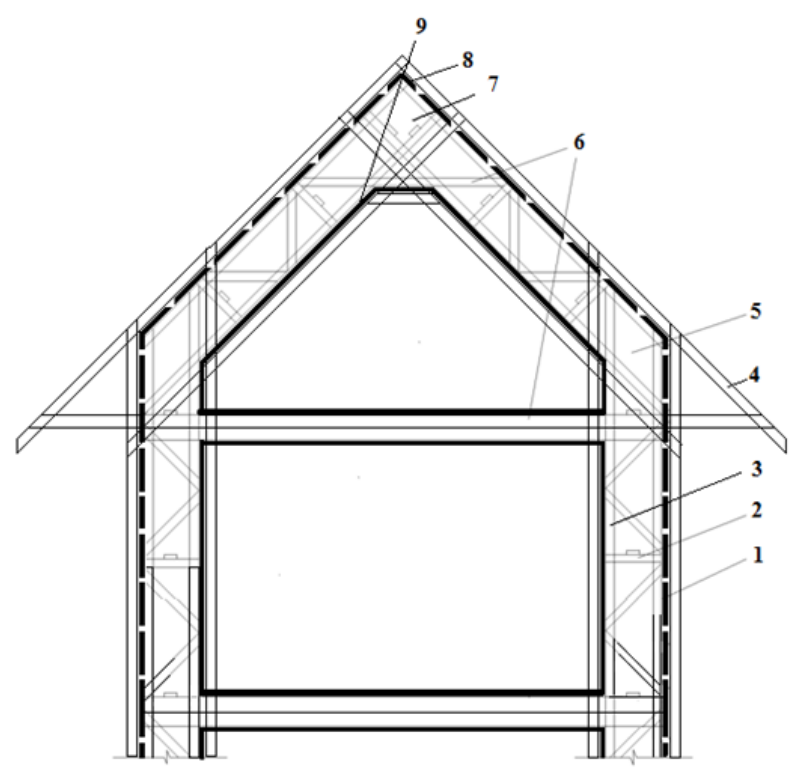

Figure 4. Patent application No. P-19-10 created building frame construction reinforcement by supplementing it with the construction strengthen elements in accordance by buildings standards requirements: $1 ; 3$ - parallel boards what forming the side edges of the building frame structure; 2 -frame width fixing perpendicularly fixing boards; 4 - extension of the frame upper edge roof structure; $5 ; 7$ - rhombus-shaped connections of construction; 6 - bundle of frame construction; 8 - outside of perforated plywood building frame structures;

9 - inside of hermetically sealed plywood building frame structures.

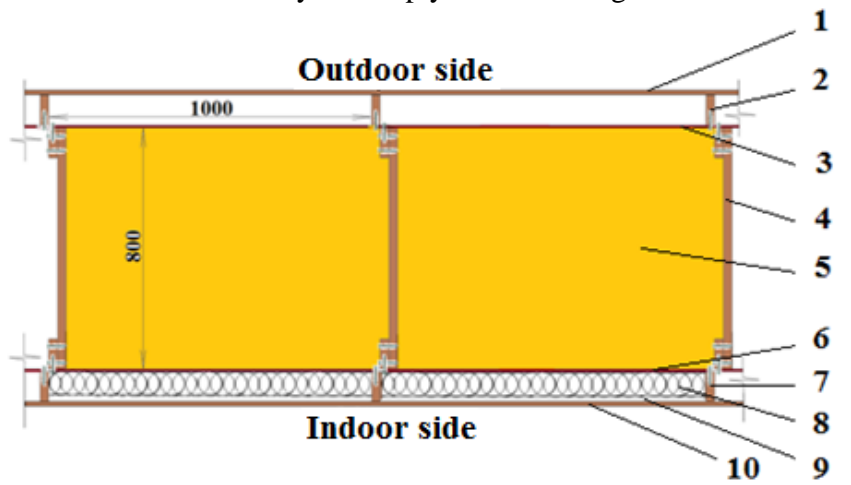

Figure 5. The building wall frame constructions are filled with thermal insulation:

1 - exterior finish; 2 - ventilated facade spacer boards; 3 - outer perforated plywood layer; 4 - building frame constructions; 5 - eco-thermal insulation layer; 6 - layer of inner hermetic plywood; 7 - internal spacers; 8 - hard stone wool slabs covered with foil; 9 - air distance; 10 - interior decoration material.

In Fig. 5 we can see a section of the exterior wall of a low or zero heat energy eco-building. That consisting of exterior finish, side-screwed $30 \times 100 \mathrm{~mm}$ boards, which perform the of additional frame strength and the ventilated facade spacer functions, perforated $10 \mathrm{~mm}$ thick exterior plywood, building frame (truss) structures filled up with $800 \mathrm{~mm}$ thick ecothermal insulation layer, $10 \mathrm{~mm}$ thick inner hermetic plywood that provides moisture barrier functions, side-screwed $30 \mathrm{x}$ $100 \mathrm{~mm}$ boards, which perform the functions of the additional frame strength, and the $70 \mathrm{~mm}$ thick hard stone wool boards placed between them covered with foil, what providing the functions of indoor fire protection, additional heat insulating and infrared radiation reflection. Above them there is a $30 \mathrm{~mm}$ thick layer of air, which ensures the reflection of infrared rays from the inner surface of the wall in the direction to the room. The air barrier is used to place in electrical and internet cables, water pipes and other communications. All this is covered with interior finishing material, preferably wooden boards, which allow to additionally providing absorbing air humidity fluctuations in the room.

In opposite of the standard method, where the wooden boards providing the distance between the ventilated gaps on the roof covering are fixed flat, in the innovative building construction solution, they were placed upright on the side. This solution increases the gap between the bottom layer of boards and the tin roof mounting boards by about 3 times, that way providing a significantly more efficient air flow, which ventilates the roof structures and function as an additional element what increase the mechanical strength of the roof. The innovative roof structure of the building, consisting of two parallel planes and two rows of boards located perpendicularly to each other and screwed together, forms a mechanically strong surface like the standard European pallet structure. Such innovative solution, by relatively low timber consumption, provides high mechanical strength of the roof structures upper surface, see. Fig. 6. 


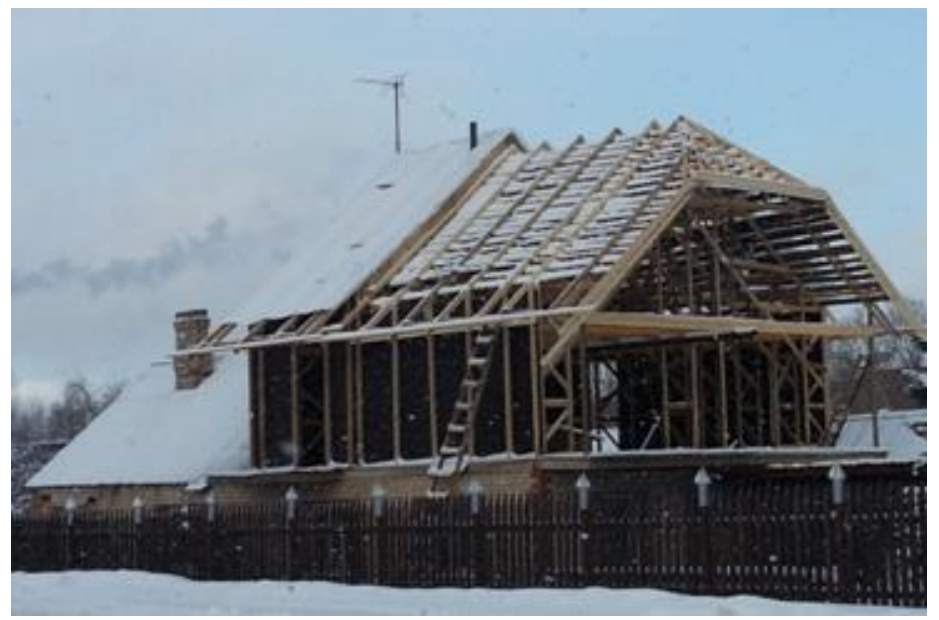

Figure 6. Innovative roof construction with increased mechanical strength creating process

To ensure the additional mechanical strength of the experimental object, an iron pipe with a diameter of $170 \mathrm{~mm}$ and a wall thickness of $4 \mathrm{~mm}$ was used to support the lower bundle, which also serves as a mezzanine floor beam. This pipe extends along the entire length of the experimental facility - right in the middle, supporting the mezzanine floor structures, and is intended to be used in the future to install an innovative air ventilation system that will supply the building inside with fresh, preheated outdoor air and serve as used air exhaust system, including high-efficiency heat recovery properties.

The windows and exterior doors of the experimental object are designed in a double version. This will prevent the possibility of creation cold bridges and their negative impact on the experimental object energy efficiency (Visockis et al., 2015.). The loggia on the building south side is planned to be completely glazed. In the cold season, when the sun shines obliquely and will shine under the roof overhang, its radiant heat will heat up the loggia and the indoor air of the building. The air will be entering in the loggia through special openings and heated by solar energy is planned to be use in the ventilation inlet, where it will be additionally heated in the recuperation system. But in summer, when heating using solar radiation is not necessary, it will not heat the premises with direct sunlight because it will be located high, close to the zenith. In this position, the overhang of the roof will provide shading, but the windows of the glazed loggia will be tilted out, dissipating excess heat to the outside.

Innovations in the new eco-building construction technology are aimed at achieving maximum efficiency at the lowest expenses, using locally sourced building materials economically as possible. As bulk thermal low-cost insulation materials can be used also unprocessed eco-materials of natural origin, such as unwashed sheep's wool, worn shredded clothing, etc. (Visockis, 2021).

The application of simple construction principles makes it possible to use the local medium-level specialization and cost labour force, ensuring the availability of such housing for people with an average income. This is important for the wide and long-lasting sale of innovative technology in the global market. In this way, the costs of building eco-houses and the harmful effects on the environment will be significantly reduced. It is an alternative solution to the use of exclusive, knotty and expensive short-live technologies that are financially available only to a narrow number of wealthy clients why want build up expensive and complex buildings, which also require expensive, frequent service and complex disposal. At the end of their service life, that does not reduce but increases the long-term harmful impact on the environment, the ecological footprint to Earth and global climate change.

Respondents from within the green building niche are critical of current UK legislation, and argue that its narrow conceptualisation fails to adequately encourage, or recognise, what they would consider to be green building forms that will contribute to substantial reductions in carbon emissions, nor does it respect locally appropriate building methods (Gibbs et al., 2014.). The future weather file for 2080 with 90th percentile data show a large increase in overheating events and is considered too extreme (Din et al., 2017.).

\section{RESULTS AND DISCUSSION}

Theoretical calculations of the experimental object static and dynamic loads have been performed by use the Dlubal RFEM calculation computer program, consider the relevant methodological materials, Latvian construction and the requirements of Eurocode standards (Ozola, 2021; Dlubal, 2021; Methodical, 2021; Eurocode No 1, 2021; Regulations, 2021; Eurocode No 5, 2021).

Calculation scheme - lattice frame with tightening clamp at the level of the ground floor and roof overhangs, see Fig.7. The clamp also serves as a ground floor beam. Additional support for the beam is in the middle of the span. All elements are made of softwood lumber, strength class C16, according to LVS EN 338 clause 5. Frame and beam pitch are $1 \mathrm{~m}$. 


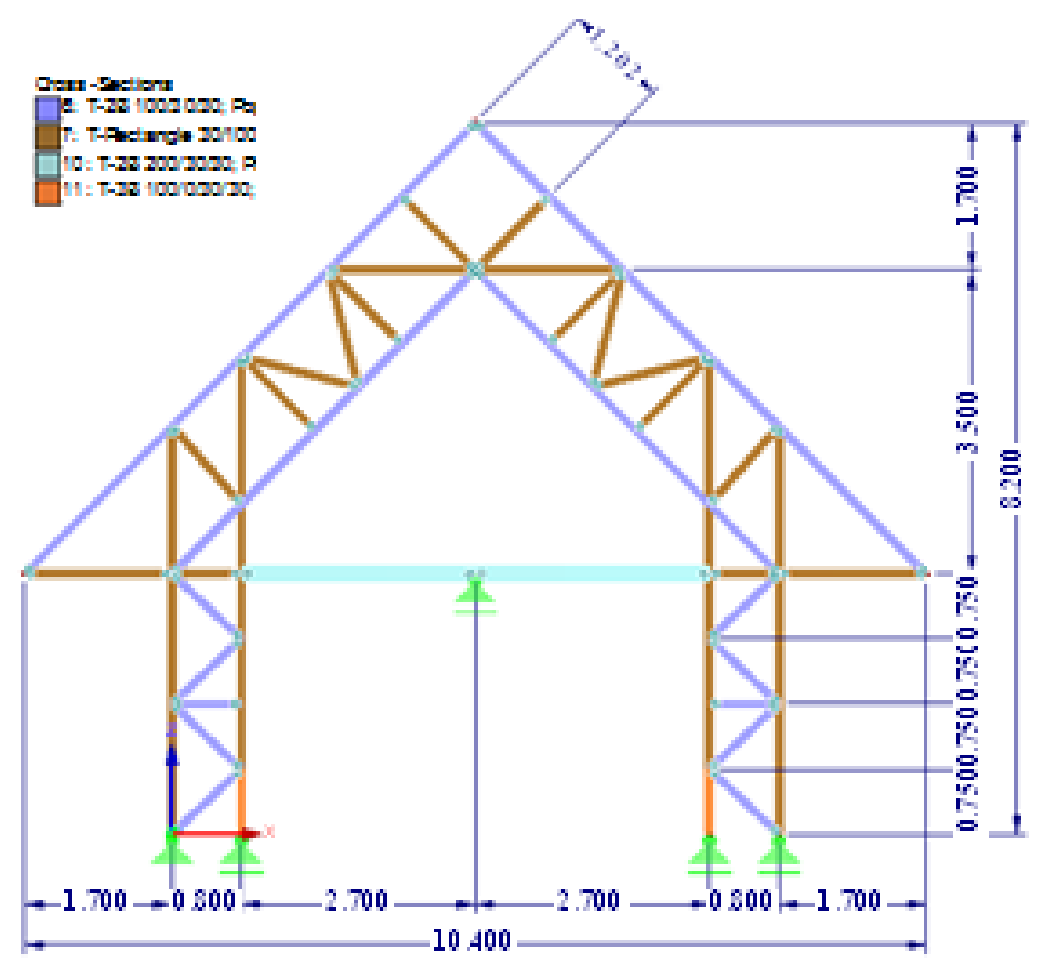

Figure 7. Lattice frame with a tightening clamp at the level of the ground floor and roof overhangs

Self-weight. Finishing materials for frames and floor beams - wood materials, density, $\gamma=4.20 \mathrm{kN} / \mathrm{m}^{3}$. Frames and floor beams are filled with thermal insulation materials, density, $\gamma=0.35 \mathrm{kN} / \mathrm{m}^{3}$. Roofing - steel sheets. Self-weight calculations are shown in Fig.8.

Results of cross-sectional tests. Cross-section tests were performed in accordance with LVS EN 1995-1-1 standard. Duration class of load exposure for self-weight - permanent exposure, for useful and snow loads - medium duration exposure and wind exposure - short-term exposure, according to LVS EN 1995 2.3.1.2. standard (2) point. Usability class 2, according to LVS EN 1995-1-1 2.3.1.3. standard (1) point. The maximal level of cross-section profitable usability is $98 \%$, see Fig. 9.

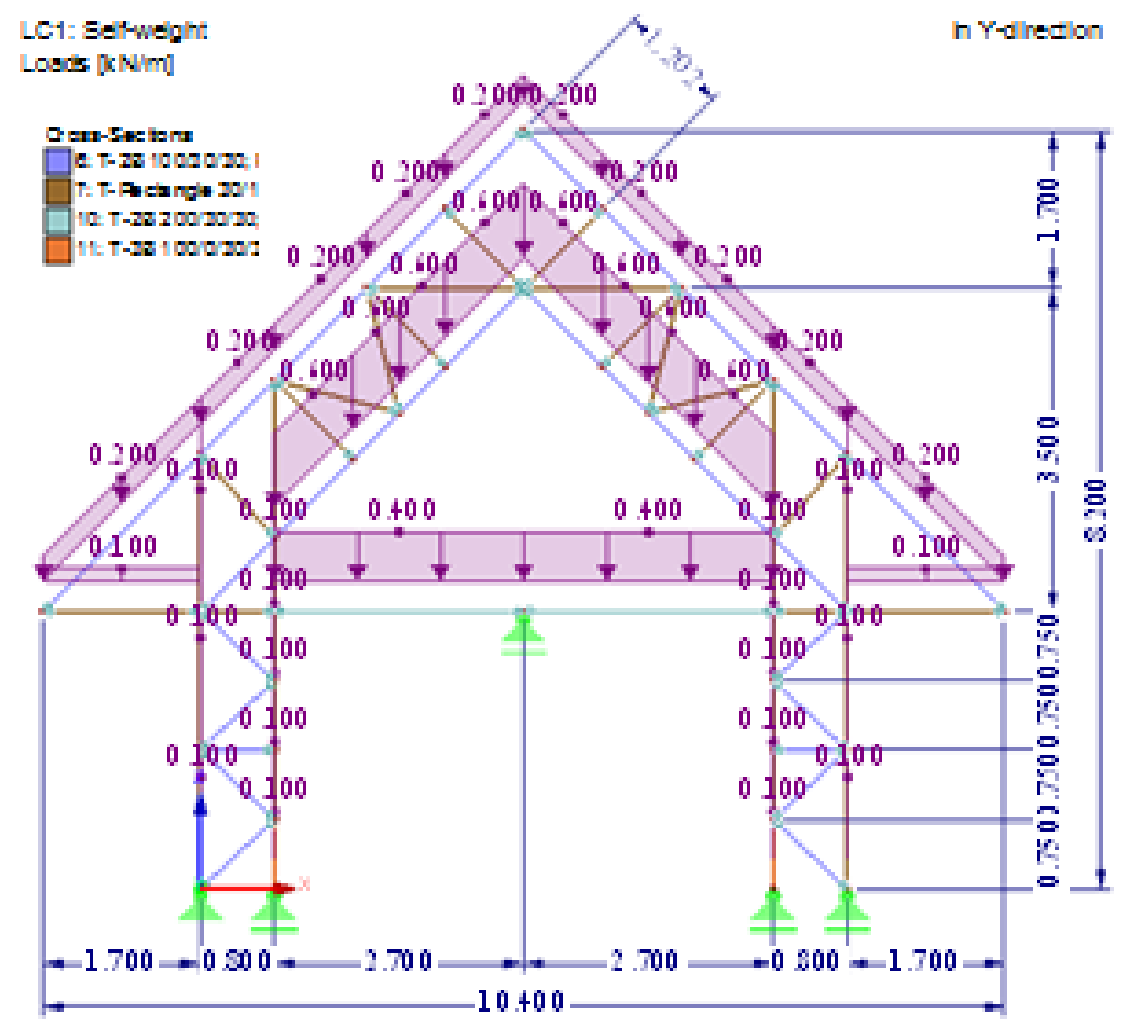

Figure 8. Scheme of building frame constructions self-weight calculation 


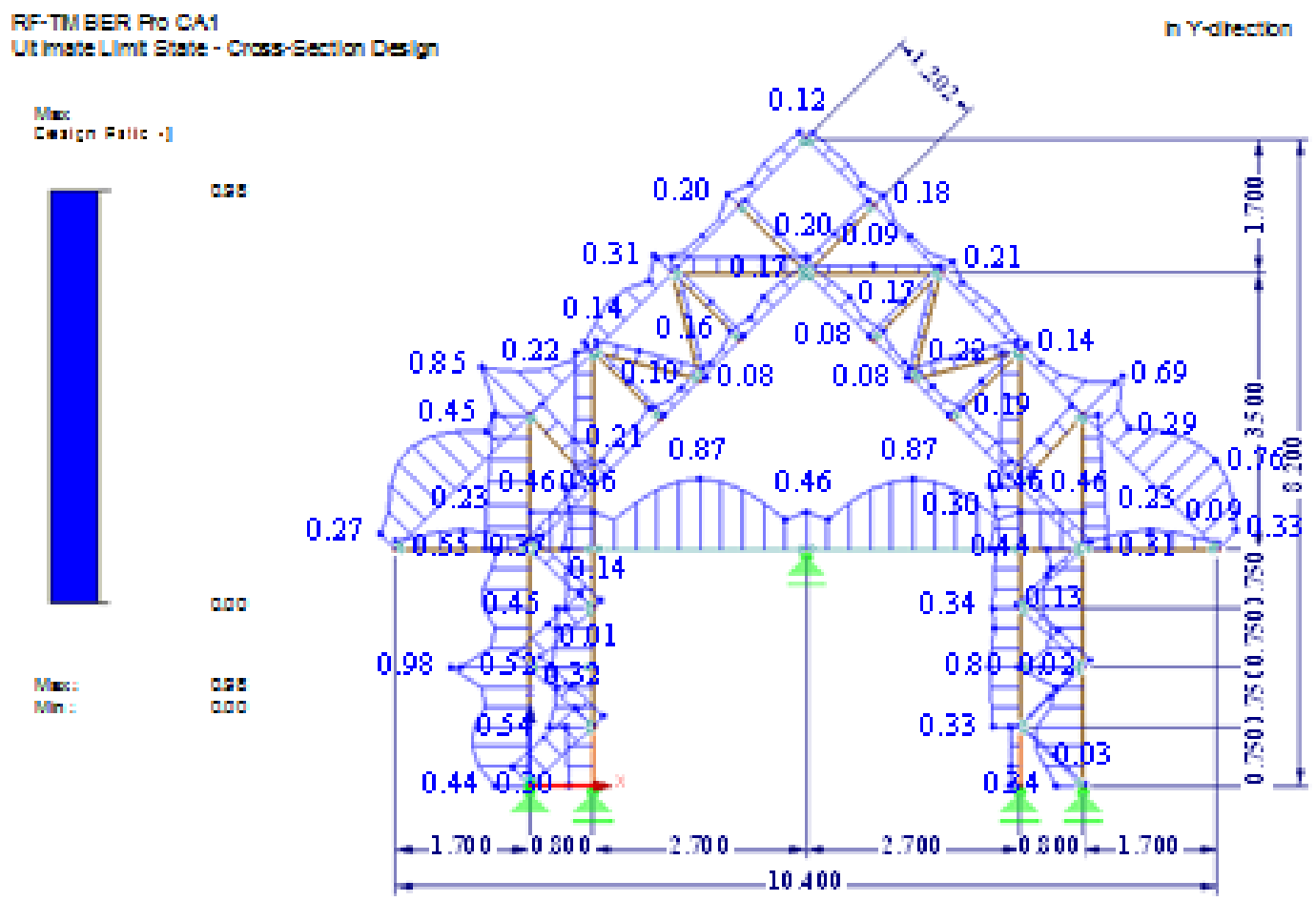

Nax Desion Fatio: 0.98

Figure 9. Results of cross - sectional tests

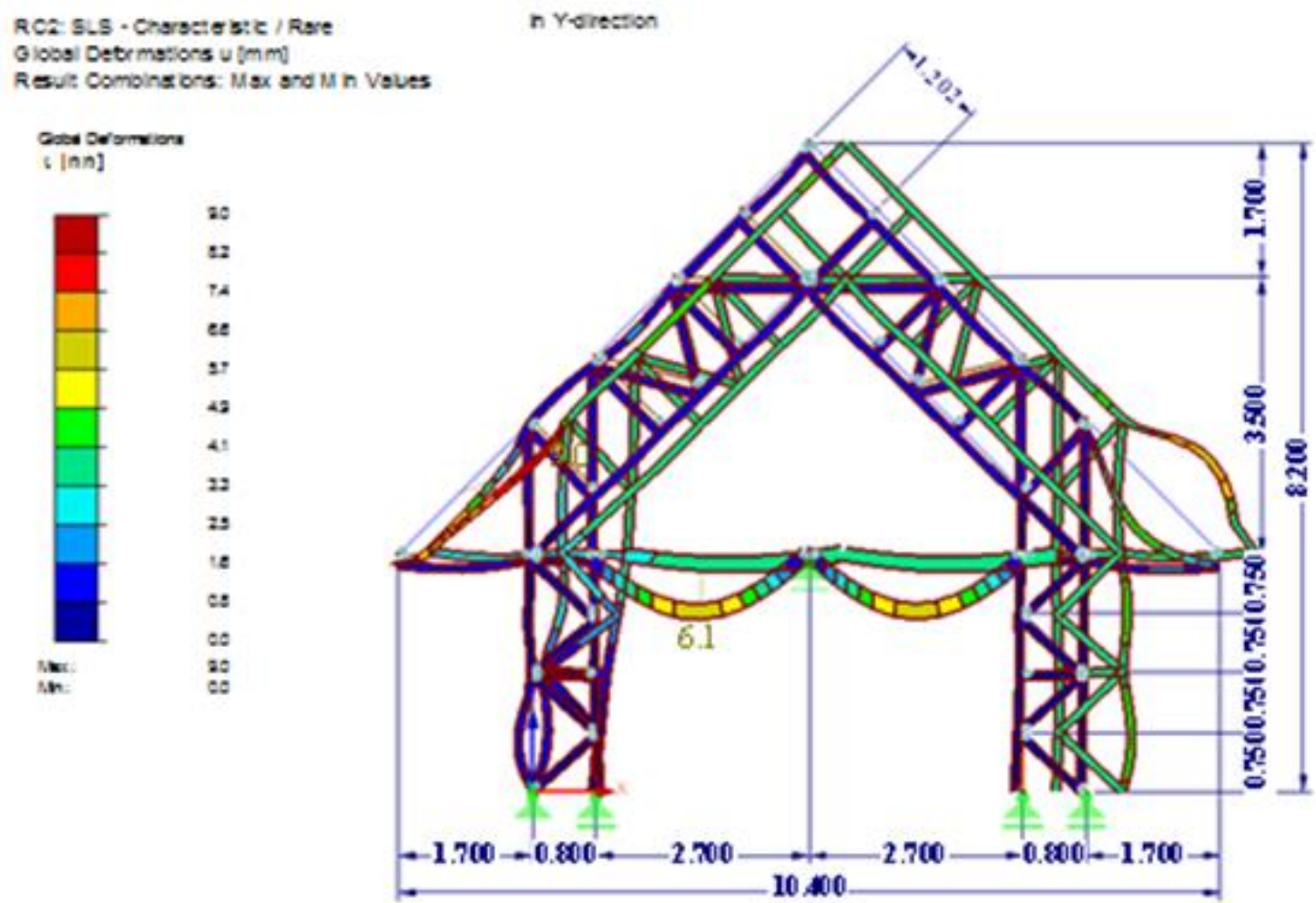

Figure 10. Maximum $9.0 \mathrm{~mm}$ and minimum $0.0 \mathrm{~mm}$ factor of deformations 120 


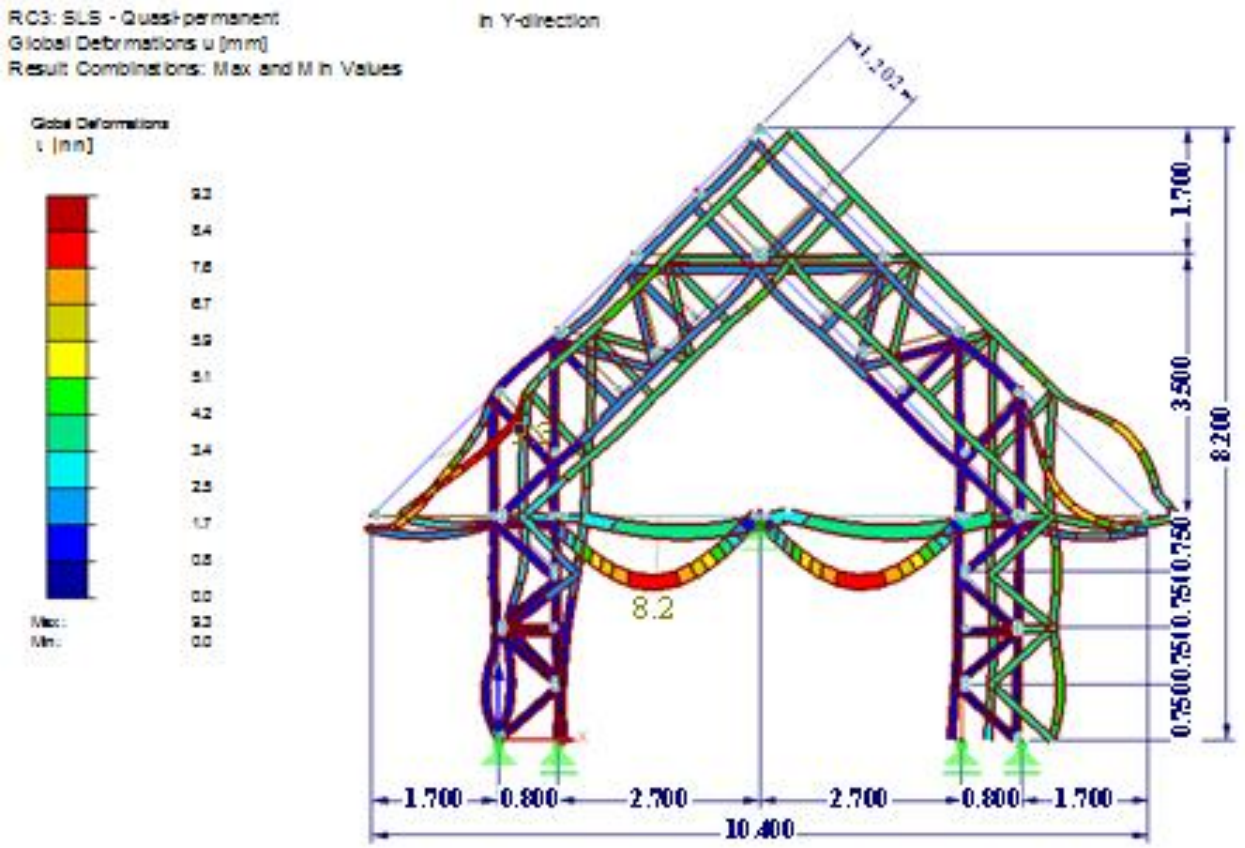

Figure 11. Maximum $9.3 \mathrm{~mm}$ and minimum 0.0 factor of deformations 110.00

Summary results of innovative wooden buildingsload-bearing frame construction calculation. The calculation scheme is created according to given lattice frame sketch, see Fig.4. Element characteristics accepted in the calculations - softwood lumber, cross section 30x100mm, strength class C16.Calculation scheme elements location is shown in the calculation report. Snow and wind load are accepted according to the location of the object - town Ludza, Latvia. Calculation report show for the accepted values of self-weight and payloads, snow and wind loads. Maximal deformation is $9.3 \mathrm{~mm}$. The maximal utilization rate is $98 \%$. This means that, considering all safety factors, the loadbearing capacity of the element cross-section is close to the maximal level of use in any combinations of the wind, snow and structural loads. Figures 10 and 11 show the calculated maximum and minimum values of the innovative building structure deformations. To avoid load changes due to material changes, it would be necessary to increase the cross-section of the entire structural frame or to strengthen the structural frame in places where the level of cross-section utilization is close to $100 \%$.

\section{CONCLUSIONS}

The lattice frame described and tested in the calculations is safe and may be used in building constructions, if provided characteristics of the elements defined in the calculations and scheme are complied with the defined loads and are not exceeded.

The experimentally created eco-building frame construction structure corresponds to the parameters set in the theoretical calculations and the constructive solution, therefore it can be used for the experimental object, practical load tests and exploitation.

The innovative building construction solution of the experimental object enables to perform energy efficiency research by filling the building frame construction with eco-thermal insulation materials included in the theoretical load calculations, as well to use other thermal insulation materials whose volumetric weight does not exceed the mass of in to calculations observed eco-thermal insulation materials.

Acknowledgments. Funding of the LLU program "Carrying out fundamental research LLU", scientific project G5"Research and development of innovative low or zero heat energy building construction technologies" and team involved in the project realisation. Funding of the LLU program "Carrying out fundamental research LLU", scientific project G9"Development of innovative technologies and their research of concentration and efficient use solar thermal energy in passive and active systems for build up energy efficient buildings" and team involved in the project realisation.

$\mathrm{GmBH}$ "Jelgavas nekustama ipasuma parvalde" for support in the implementation of research

Association "ECOtechnologies" for support in the implementation of research.

\section{REFERENCES}

1. Din A., Brotas L. 2017. Assessment of climate change on UK dwelling indoor comfort. Energy Procedia, Vol. 122, pp. 21-26. https://doi.org/10.1016/j.egypro.2017.07.296

2. Dlubal RFEM 5 \& RSTAB 8 (in Latvian: Dlubal RFEM aprēḳinu datorprogramma). Available at https://www.dlubal.com/en/ support-and-learning/learning/videos/000066 (Accessed: 16/02/2021) 
3. Eurocode No 1 LVS EN 1991-1-1; LVS EN 1991-1-3; LVS EN 1991-1-4 (in Latvian: Eirokodekss Nr. 1 LVS EN 1991-1-1; LVS EN 1991-1-3; LVS EN 1991-1-4). Available at https://www.lbskonsultants.lv/apmacibas/eirokodekss-nr-1/ (Accessed: 17/02/2021)

4. Eurocode No 5 "Design of wooden structures" - LBPA (in Latvian: Eirokodekss Nr. 5 «Koka konstrukciju projektēšana» - LBPA Available at https://www.google.com/search?q=LVS+EN+338\&oq=LVS+EN+338\&aqs=chrome..69i57.1079j1j15\& sourceid=chrome\&ie=UTF-8 (Accessed: 17/02/2021)

5. Gibbs D., O’Neill K. 2015. Building a green economy? Sustainability transitions in the UK building sector. Geoforum, Vol. 59, pp. 133-141. https://doi.org/10.1016/j.geoforum.2014.12.004

6. Hemp or Canans for heat insulation (in Latvian: Kạ̣epes jeb Kanaizolssiltinājumam). Available at http://buvfizika.lv/wpcontent/uploads/2011/09/Kanepes_Kanaizols.pdf (Accessed: 07/06/2021)

7. Home insulation with sawdust (in Latvian: Mājas siltināšana ar zāǵu skaidām) Available at https://www.la.lv/majas-siltinasana-arzagu-skaidam-2 (Accessed: 17/02/2021)

8. Methodical Materials LVS en 1990 Basic Principles of Design (in Latvian: Metodiskie Materiāli LVS en 1990 Projektēšanas Pamatprincipi). Available at https://www.scribd.com/doc/222413337/Metodiskie-Materiali-Lvs-en-1990-Projektesanas-Pamatpri ncipi-1-1 (Accessed: 17/02/2021)

9. Ozola L. Innovative frame wood constructions application concept development for high energy efficiency buildings (in Latvian: Mērķsadarbības līgums LV/2005/EK-01. Eirokoda ieviešana nesošo konstrukciju projektēšanas praksē Latvijā Koka konstrukciju projektēšana saskaṇā ar LVS EN 1995-1-1.)

10. Regulations on the Latvian construction standard LBN 002-19 "Thermal engineering of building envelopes" (in Latvian: Noteikumi par Latvijas būvnormatīvu LBN 002-19 "Ēku norobežojošo konstrukciju siltumtehnika") Available at https://likumi.lv/ta/id/307966noteikumi-par-latvijas-buvnormativu-lbn-002-19-eku-norobezojoso-konstrukciju-siltumte (Accessed: 17/02/2021)

11. Regulations on the Latvian construction standart LBN 206-14 "Design of wooden constructions" (in Latvian: Noteikumi par Latvijas būvnormatīvu LBN 206-14 "Koka būvkonstrukciju projektěšana") Available at https://likumi.lv/ta/id/271233-noteikumipar-latvijas-buvnormativu-lbn-206-14-koka-buvkonstrukciju-projektesana (Accessed: 17/02/2021)

12. Visockis E. 2021. Construction and application of high energy effectivity mobile micro-eco-houses for receiving prophylactic procedures and self-isolation of Coronavirus Covid-19 and other diseases // Rural Development 2021 Challenges of Sustainable Bioeconomy and Climate Change. VDU. SCOPUS database. Lithuania, Kaunas, 2021.

13. Visockis E. Received patent: “Wall and roof cross frame building construction”. Application number P-19-30, date 18.06.2019. Number of patent: LV 15476 B. Date of application publication: 20.01.2020., date of patent publication: 20.04.2021.

14. Visockis E., Selegovskis R., Pleiksnis S. 2015. Heat losses decreasing possibilities through building windows. Engineering for Rural Development, pp. 184-189.

15. Visockis E., Skujans J., Gusta S., Pleiksnis S., Selegovskis R. 2019. Patent application: "Wall and Roof building structure". Application date 21.02.2019, number P-19-10. Applicant: Latvia University of Life Sciences and Technologies. 